\title{
The Implication of humor discourse in the Tonight Show television program
}

\author{
Dita Intan Pramukti
}

Indonesian Language and Literature Department, Languages and Arts Faculty, Universitas Negeri Semarang, Indonesia

Email: dintanpr@students.unnes.ac.id

\author{
Asep Purwo Yudi Utomo \\ Indonesian Language and Literature Department, Languages and Arts Faculty, \\ Universitas Negeri Semarang, Indonesia \\ Email: aseppyu@mail.unnes.ac.id
}

\begin{abstract}
Humor discourse is a form of language that deviates from the rules of speech and conversation principles. Humor is a form of contradiction or deviation from the constraints of language. One of the humor discourse that presents language use conditions with a particular speech strategy is NET TV Tonight Show. This television program may contain speech offenses at the event. This study aims to describe and explain the implicature of humor discourse in the Tonight Show. In this study, researchers used a qualitative approach with the content analysis method and the pragmatic theory approach. The data is in the form of humor discourse in the Tonight Show television program, which is aired on NET TV. Still, researchers take the data from the Tonight Show uploaded on YouTube, collected by recording and recorded techniques. The data is analyzed by using an interactive model. The results showed that the implicature of humor discourse in the Tonight Show was in the form of mentioning, insinuating, revealing,
\end{abstract}


protesting, informing, rejecting, accusing, asking, and saying. The benefit of this study is to know the humor discourse contained in the Tonight Show.

Keywords: Humor Discourse, Talk Show, Tonight Show, NET TV

\section{INTRODUCTION}

In everyday life, humans can not be separated from the use of implicature even the implicature is one part of everyday speech. Implicature can be defined as implied meaning which is contained in an utterance even though the utterance is not stated clearly. In understanding the implicature, it can not be separated from the cooperation principle between two speakers in a conversation. Implicature is very important to be known by both parties during the conversation interaction. It is because in order to avoid misunderstanding in the discussion. Implicature is a study of pragmatics. Implicature can be understood through context. The conversational implicature is part of pragmatics that can define the implied meaning of speech that caused by the principle of conversation violation.

In pragmatics, there is a humor discourse. Humor is a short story that tells a funny event to make the reader laugh. The humor can be caused by several things, namely the behavior of the perpetrators, the common events but misleading, the criticism of the situation, ignorance, misunderstanding, the cultural differences, and many other things. Humor can also be created through stimulation or jokes through the use of language with certain methods. Generally, humor is known as something that can cause laughter. Whereas in terms of the language, humor is a form of contradiction or deviation in the rules of language. It causes humor discourse is different from serious discourse.

In pragmatics, there is a humorous discourse. Humor is a short story that tells a funny event that is expected can make the reader laugh. The humorous of a humor can be caused by several things, namely the behavior of the actors, commonly events but misleading, criticism of the situation, ignorance, misunderstanding, cultural differences and other things. Humor can also be created through stimuli or jokes through the use of language with certain methods. Generally, humor is known as something that can cause laughter. While in the aspect of language, humor is a form of contradiction or deviation in the rules of language. It causes humorous discourse is different from serious discourse.

Humor can be classified to be successful if the spoken humor can be 
directly accepted by the recipient of humor in accordance with the intent of the humorist's utterance. According to the sensory criteria, humor consists of many types, namely auditive humor, visual humor, and verbal humor. According to the material criteria, humor consists of sadistic humor, political humor, puzzle humor, and sex humor. While according to ethical criteria, humor can be divided into healthy humor and unhealthy humor. The last, according to aesthetic criteria, humor is derived into subtle humor that is implicitly uttered and crude humor that is explicitly uttered.

There are many television programs that present humor discourse, including talk show television program about Tonight Show. The program that was hosted by Desta, Vincent, Hesti, and Enzy presented humor with specific language technique. Tonight Show is a comedy program that aired from Monday to Friday. This program has given a new atmosphere in the world of entertainment, especially humor program.

Tonight Show consists of several segments including: Who is, Question and Answer of Vincent Desta (\#TanyaVincetDesta) MTVD (Music Tonight Vincent Desta), Tonight's Radio, Tonight in News, Musical Drama, Tonight's Poetry, Tonight's Jokes, Selinting (intermezzo but contain important information), Tonight's Update, Tonight's Headline, Tonight's Clinic, Kamis (Mystery Thursday) and Tonight's Challenge which is always awaited by viewers. Tonight's Challenge consists of various games which are played alternately every day, including: Seberapa paham (How deep you understand), Jawab Aku dengan Satu Kata (Answer Me with One Word), Look In To My Eyes, Kiss Kiss Cup Muach, Mungkinkah (Could It Be), Kursi goyang (kuyang) (Rocking Chair (kuyang)), Heads Up, Tebak Gaya Jawab Jujur Kali (Jajuli) (Style Guess Answer Honestly (Jajuli)), Put Your Shoes Up, Tebak Siapa (TeSi) (Guess Who (TeSi)), Fun Fact, Tebak Bibir (Guess Lips), Tebak Gambar (Guess Pictures), Pernah Atau Tidak Pernah (Ever Or Never), Setuju Atau Tidak Setuju (Agree Or Disagree), Berpacu Dengan Mas Dedi (Compate With Mas Dedi), Diantara 2 Pilihan (Between 2 Choices), Buat Garis Lurus (Make Straight Line), Tonight Spelling, and Truth or Dare.

Nowadays, humor discourse is important to be analyzed because almost everyone faces cuteness in everyday life. Besides, humor also has many functions. Martin (2007: 15; Bell and Pomerantz, 2016: 28), categorized the function of humor into three categories, namely the cognitive and social benefits of positive emotional excitement, can relieve and overcome tension or stress, and the last is to use humor for communication and social influence 
Humor also contains a lot of implicature, although the speaker of humor may not realize. The pragmatic perspective states that the implicature that arises from the principle of conversation violation is a great potential for the creation of humor. Thus, it needs to be researched further about the implicatures contained in the creation of humor in Tonight Show.

Humor contains many implicatures, although it is not realized by the speaker. Implicature that comes from the principle of conversation violations is a great potential for the creation of humor by the speaker. This is the reason that needs to be studied further about the implicatures contained in the creation of humor in the Tonight Show.

The previous study on humor discourse had been conducted by Irfansyah and Sumarlam (2017) entitled "Implicature of Humor Discourse of Ini Talk Show on Net TV". The study uses a qualitative approach with content analysis methods and pragmatic theory approach. The data in the form of humor discourse in the talkshow that aired on NET TV which was collected by recording and note technique. The validity of the data was checked by data triangulation. The data is analyzed by using an interactive model. The results of the study show that (1) the implicatures of the humor discourse in the Ini Talkshow in the form of mentioning, stating, rejecting, insinuating, protesting, accusing, claiming, asking/ begging, ridiculing, expelling, and threatening; (2) maxims of cooperative principle violation including maxim of quality, maxim of relationships, and maxim of manner; and (3) in addition to violating the cooperative principle, implicature explication also violates positive and negative politeness. The violation was done intentionally solely to create an atmosphere of humor for the viewers.

Research on humorous discourse had been conducted previously by Irfansyah and Sumarlam (2017) entitled "Implicature of Humor Discourse of Ini Talk Show on Net TV". The study uses a qualitative approach with content analysis method and pragmatic theory approach. The data are in the form of humor discourse of the Ini Talkshow that aired by NET TV, which was collected by record and note techniques. The validity of the data was checked by data triangulation. The data was then analyzed by using an interactive model. The results of the study show that (1) the form of implicature of humor discourse in the Ini talk show in the form of mentioning, stating, rejecting, insinuating, protesting, accusing, claiming, asking / begging, ridiculing, expelling, and threatening; (2) maxims of cooperative principle violation include quality maxims, maxims, relationships, and manner maxims; and (3) in addition of 
the cooperative principle violation, implicature disclosure also violates positive politeness and negative politeness. The violation was done intentionally and solely to create a situation of humor in the audiences' mind.

The similiraty between the study conducted by Irfansyah and Sumarlam (2017) with this study is that they both discuss the implicature of humor discourse. The difference between Irfansyah and Sumarlam (2017) study with this study is that in Irfansyah and Sumarlam (2017) study took the data on the Ini Talk Show, whereas in this study the researcher took the data in the Tonight Show.

The similarity of Irfansyah and Sumarlam research (2017) with this research is that they both discuss the implicature of humor discourse. The difference between Irfansyah and Sumarlam (2017) research with this research is that in Irfansyah and Sumarlam (2017) research took the data in the Ini Talk Show, whereas in this study, the researcher took the data in the Tonight Show.

Wiwiek Dwi Astuti (2017) has also studied the "Implicatures of Conversation in Sentil Sentilun Speeches on Metro TV". This study aims to describe (1) the form/ function of the conversational implicature and (2) the cooperative principle violation of and the politeness principle in the talk show "Sentilan Sentilun" on Metro TV especially in the episode "Who Wants to Joins the Cart?' The method used is refer method with the technique of recording the utterances / utterances of the characters and / or guests who were presented at the event. The results that were obtained related to the form/ function of the implicature are the use of representative (assertive), directive (imposif), expressive, commissive, and declarative speech. Furthermore, the cooperative principle violation and all the maxims emphasize clashes and games (joke).

Wiwiek Dwi Astuti (2017) has also researched the "The Conversational Implicature in the Sentil Sentilun talk show on Metro TV". This study aims to describe (1) the form / function of the conversational implicature and (2) the cooperative principle violation and / the politeness principle in the talk show "Sentilan Sentilun" on Metro TV with the episode "Who Joins the Cart ??' The method used is simak method with the technique of recording the utterances of the characters and / or guests who were presented at the event. The results obtained related to the form / function of the implicature are the use of representational (assertive), directive (imposif), expressive, commissive, and declarative utterances. Furthermore, the cooperative principle violation with all the maxims prioritized clashes and games (joke). 
The similarity of the study conducted by Wiwiek Dwi Astuti's (2017) with this study is that they both discuss the implicature. The difference between Wiwiek Dwi Astuti's (2017) study and this study is that Wiwiek Dwi Astuti's (2017) study examines of the cooperative principle violation and conversational implicature, whereas in this study the researcher examines the implicature of humor discourse.

In addition to the two studies above, the thesis by Rahayu Sulistiani (2018) also studied "The Conversation Implicature in Humor Discourse of Cartoon Comic Sentilan Bung Sentil". This study aims to describe the conversation implicature as supporting humor that contains in the Sentilan Bung Sentil cartoon of humor discourse. This study uses descriptive qualitative method. This study produces descriptive data in the form of conversational implicature as supporting humor that contains in Sentilan Bung Sentil cartoon comic of humor discourse. The result of this study is in the cartoon comic discourse of Sentilan Bung Sentil that contains of 38 strip comics identified, there are 92 utterances that contains of conversational implicature which include representative implicatives. There are 20 or $21.7 \%$ in the form of states, 2 or $2.1 \%$ in the form of reporting, 20 or $21.7 \%$ in the form of indicating, 10 pieces or $11 \%$ in the form of mentioning. Then the directive implicature, there are 2 or $2.1 \%$ in the form of asking, 2 or $2.1 \%$ in the form of demanding, 4 or $4.3 \%$ in the form of suggesting. The next is the expressive implicature, there are 2 or $2.1 \%$ in the form of praising, 22 or $24 \%$ in the form of criticizing, 6 or $6.5 \%$ in the form of complaining. Then in the commissive implicature, there is 1 or $1 \%$ in the form of threatening. And the last is the implicature isbati, there is 1 or $1 \%$ in the form of prohibiting. In this study, several implicatures were found that were more classified in the form of satire or social criticism of corrupt government and officials. All forms of utterance in the Sentilan Bung Sentil cartoon comic are efforts made to provide a description of the social phenomena that occurred in the community at that time. All of that was played by Bung character and other characters by criticizing. The cartoon comic of Sentilan Bung Sentil is a political humor in the form of satire or criticism against the performance of the government and government who have high power by causing humor that makes the audience laugh.

The similarity of the study by Rahayu Sulistiani (2018) with this study is discussing the implicature. The difference between Rahayu Sulistiani's study (2018) and this study is that in Rahayu Sulistiani's study (2018) researchers take the data in humor discourse that contais in comics, while this study takes the data from speech show. 


\section{RESEARCH METHOD}

This study is a qualitative research with content analysis method by using pragmatic theory approach. The object that was studied is humor discourse in the Tonight Show which was aired by the NET TV television station. But, researchers only took the data from two segments uploaded on YouTube on March 17, 2020. The data was collected by using the free listening technique and the note taking technique. It means that researchers only act as observers of the use of language by the informants. And researchers are not involved in the events being examined. The data collection techniques are divided into 4 , namely: (1) by using the see basic techniques. (2) listening. (3) oral data transfer in written form or the data transcription. (4) note-taking research technique. The presentation of the results used in this study is using informal presentation technique, namely the presentation of data by using ordinary words.

This study is a qualitative research with content analysis method by using pragmatic theory approach. The object that is studied was humor discourse on the Tonight Show which was aired by NET TV television station. In addition to airing on the NET TV television station every Monday to Friday at 21:00 WIB, the Tonight Show was also uploaded on a YouTube channel by the Tonight Show. But it is only a few segment. So researchers only took the data on three videos uploaded on the YouTube Tonight Show channel. The first video entitled "Audience Can Only Roughly Make Song, But It Is Still Fun!" which was uploaded on March 21, 2020. The second video with entitled "Apes! Desta's Behavior Tells Vincent To Be a Duck Coop" which was uploaded on March 18, 2020, and the third video entitled "Desta Is Not Able to Listen to Bastian's Flattery” uploaded on March 24, 2020. Researchers found 13 data in the selected video. The data were collected by using simak bebas and note techniques. It means that researchers only act as observers of the use of language by the informants. And researchers are not involved at all in the event being examined.

The data collection techniques are divided into 4, namely: (1) by using the basic technique of simak technique. The basic technique of simak technique that the researcher watched the two videos that are used as the data and then watched the video. (2) listening. Researchers used earphones to sharpen hearing. (3) the spoken data transferred in written form or data transcription. After the researcher analyzed and listened, the researcher found the data which 
will then be transferred in written form. (4) note-taking technical research. The researcher uses recorded media when collecting the data. The presentation of the results used in this study uses informal presentation technique, namely the presentation of data by using ordinary words.

\section{RESULT AND DISCUSSION}

This part covers the implicature of humor discourse in the Tonight Show program. The implicature has a form of the intention that is not expressed literally through the speech by the speaker, but it is implicited. In the context of humor discourse in the Tonight Show program, the implicature form was created intentionally through cooperative principle violation or the politeness principle to give the effect of humor to the viewers.

In this section, it covers the implicature of humor discourse on the Tonight Show. The implicature has an intention that is not expressed literally through the speech of the speaker, but it is implicit. In the context of humor discourse in the Tonight Show program, the implicature form was intentionally created through the cooperative principle violation or the politeness principle to give the effect of humor to the audience. This research took the data from three Tonight Show videos of talk show Tonight Show that were uploaded on YouTube.

\section{The Implicature Form of Humor Discourse in the Tonight Show Program}

Communicative interactions of the host and guest stars that occur in humor discourse in the Tonight Show program often use implicatures to express their messages or desires. Some of the implicatures stated contain humor elements that can give a funny effect to the viewers. The following are some data that researchers have found.

Communicative interactions that occur in humor discourse in the Tonight Show program, the host and guest stars often used implicatures to express their messages or desires. Some of the implicatures stated contain humor elements that can give a funny effect to the audience. The implicature was spoken spontaneously by the speaker to the speech partner. Although, the speakers and the speech partners have understood each other what is the maximum implied by the speaker. So that there was a smooth communication to create a situation of humor in the Tonight Show. Here are some data that researchers have found. 
The first data quoted that the speaker (Desta) did not mean to ask for an answer. With a questioning mode, he wants to speak representatively, in mentioning the speech partner (cameraman) who was playing tennis. The positive politeness violation caused the formation of mention implicature.

(Context: Desta and Vincet are interviewing Masayu Clara, but cameramen are talking to each other, then they are reprimanded by Desta.)

Desta: "Sorry ... sorry ... sorry ... sorry. Please cameramen don't talk to each other. You know the audience is quiet, but you talk to each other.

Vincent: "technical please"

Desta: "are they playing tennis?"

Vincet: "technical"

Desta: oh technical, sorry sorry "(TS-17/03/20)

The results of the analysis are in accordance with the results of Nur Ifansyah \& Sumarlam (2017) which stated that the speaker (Meriam) in the quotation actually did not intend to ask for an answer. With the questioning mode, he wanted to speak representatively, namely to call the speech partner (Nunung) as a book wedge. The implicature said that it was created as a result of positive politeness violation. Such a term is a threat to the wishes of the speech partner so that what they have is appreciated by the speaker.

Implicatures for representative categories are also can be seen in the following discourse. The speaker (Desta) gave a contribution that is not supported by adequate evidence. The behavior is: he will get drunk if he tries to use a handsanitizer by Masayu, it is not rationally acceptable. It has a humor effect for the audience, which is supported by the serious attitude of the speaker. The speech act tells the discourse to imply the intention of stating something that is not supported by evidence, it violates the quality maxim.

(Context: Desta wants to try the handsanitizer made by Masayu)

Desta : "let me try"

Masayu : "yes, that feels ..."

Desta : "does it have alcohol effect?"

Masayu : "yes, it has 70\% of alcohol"

Desta : "wah, I'm afraid of getting drunk"

Vincent : "it's not such alcohol"

Masayu : "so don't drink it bro" (TS-17/03/20) 
The results of the analysis are in accordance with the results of Nur Ifansyah \& Sumarlam's (2017) study which states that speech acts inform the discourse implying the intention to state something that is not supported by evidence and it violates the quality maxim.

The next data contains quipping implicature with express mode. The implicature is caused by cooperative principle violation and politeness principle. What the speaker (Vincent) meant was not intended for the speech partner (Masayu), but it was given to Desta. The quality maxim violation made laughter for the audience because they know these facts distorted. The positive politeness is violated because satire is an action that is not appreciate the satirical party.

(Context: Vincet was asking Masayu Clara about the role she played while acting in FTV)

Vincent: "And you always get a bitchy role, or a ... antagonist ..."

Masayu: "No ... not bitchy actually. In FTV, the standard of the first scene is definitely angry, the main role of the girl and the man are definitely fighting "

Vincent: "Ha ... you are not angry in FTV only, but everywhere" (while pointing at Desta who is next to him)

Masayu : "am I angry everytime?"

Vincent : "yesssss"

The results of the analysis are in accordance with the results of the study conducted by Nur Ifansyah \& Sumarlam (2017) which states that implicatures arise from the cooperative principle violation and the politeness principle.

(Context: Desta asked Masayu why she was not tired when acting in FTV. Desta compared him to being tired of acting in FTV, so he decided to play in only two titles.)

Desta : "but Masayu, to be honest I acted in FTV for two times and I gave up"

Masayu : "why bro?"

Desta : "I was tired, it usually conducted four days in a week, how many days now for a week?"

Masayu : "four or five days in a week now"

Desta : "I asked for three days and it must be rushed"

Masayu : "bro, no wonder if you were tired" 
Desta : "that's why, and I did two titles"

Masayu : "I ever did in three days"

Desta : "Hesti also ever became a queen of FTV"

Hesti : "but it was in eight days, it was impossible in three days"

Enzy : "maybe you were extras" (TS-17/03/20)

Speech speaker (Enzy) ask questions, but carry out the pragmatic function of protesting. The action is a form of evaluation of the words of the speech partner (Desta) which can result in the positive face of the speech partner being threatened. The protest delivered was actually able to arouse the audiences' laughter because the word contained elements of jokes, which differed greatly from what was protested. The results of the analysis were in accordance with the results of Nur Ifansyah \& Sumarlam's (2017) study which stated that this action as a form of evaluation of what the speech partner expressed.

Context: Masayu was challenged by Vincent and Desta to arrange the sentences provided so that it became the title of FTV, then Desta, Vincent, and Masayu demonstrated the scene in FTV cage"

Desta : "my heart was apparently taken by a cendol ice seller in a duck

Masayu : "haa... it can be"

Desta : "can this?"

Masayu : "yesssss" to him)

Desta : "you're the duck cage" (while pointing at Vincent who was next

Vincent : "I can be the duck, why I'm be the cage?"

(Everyone laughed) (TS-17/03/20)

In the conversation above, there are speech acts that are not in accordance with the function carried. The speaker (Vincent) replied the request of his partner with notifying mode, but it contains refusing implication pragmatic. The humor effect was raised by the nonconformance of the speaker's contribution to the topic of conversation, namely asking because he was appointed to be a duck cage by a speech partner. Generally, the unsustainability of a rejection in a conversation is carried out on sociocultural consideration. If the refusal function is very clearly expressed, then the speech acts will be less polite, which will cause disruption of social relations. However, in the humor discourse, these actions are only done to bring out humor. The results of the analysis are in 
accordance with the research results of Nur Ifansyah \& Sumarlam (2017) which states in the humor discourse, that action is solely for humor.

Contex : Desta, Vincent, and Mayasu demonstrated the title of FTV that had been chosen

Desta : "wah there is a chicken cage .... I need eggs"

Vincent : "duck egg?"

Desta : "chocken egg"

Masayu: "for what?"

Desta : "I haven't eaten chicken eggs in a long time. Is there anyone??"

Masayu : "thief ..... thief"

Desta : "Don't be a thief, you look down. How come he even accused me of being a thief"

Vincent : "Cendol seller is burnt by the masses"

Desta : "no please"

The following data raises the pragmatic implications of accusing. These implications arise due to a positive politeness violation. The accusation addressed to the speech partner (Desta) threatens a positive face because the effort of the speech partner as a cendol ice seller is infused with accusations. The fact is, the audiences' laughed because the accusation contain humor. The results of the analysis are accordance with the results of study conducted by Nur Ifansyah \& Sumarlam (2017) which states the implications of accusing arising due to positive politeness violation. These accusations threaten a positive face because the efforts of the speech partners are not respected, instead they are accompanied by accusations.

(Contex : Desta greets the audience who was the host of the television program that aired after Tonight Show, namely Malam Malam.)

.Desta : "Hallo audience, good evening. The audience of Malam Malam team who support Tonight Show.

"Later, we will reply but we will not watch, because we want to go home earlier, okay?"(Audience laughs)

Enzy : "we are tired of having a rest"

(the audience laughed and cheered)

Hesti : "thank you for coming here, eh Rafael smash huh? (while pointing at Surya who one of the hosts of Malam Malam who happened to use 
shorts like Rafael used on the Tonight Show in the previous episode)

Surya : "yesssss" (TS-17/03/20)

Desta as a speaker and host of Malam-Malam also as a speech partner. The data is an impliciture in representative category. The speaker (Desta) said that he would reply to what the speech partner (Malam-Malam host) had done, namely watching the show, but afterwards Desta said that he wanted to go home and did not want to watch because he wanted to go home early. The speech act intends to state something that is not supported by evidence, thus it violates the quality maxim. In addition, the speaker (Hesti) in the quote above actually did not intend to ask for an answer. With the questioning mode, he wanted to speak in a representative manner, namely to call the speech partner (Surya) as Rafael Smash because Surya was wearing shorts that is similar to Rafael. The term can threaten the speech partner's desire for what they have is appreciated by the speaker. The implicature stated that there is an effect of positive politeness violation. The results of the analysis are in accordance with the results of a study conducted by Nur Ifansyah $\&$ Sumarlam (2017) which states that the implicature was created as a result of positive politeness violation. Such a term is a threat to the wishes of the speech partner, so that what they have is appreciated by the speaker

(Contex : Vincent gave the Maracas musical instrument to Asteriska who one of the voice members who had a tiny body)

Vincent : "Adek... do you want it?.... which early childhood education are you from, Adek?" (TS-17/03/20)

The speaker (Vincent) in the quote above actually did not intend to ask for an answer. With the questioning mode, he wanted to speak in a representative way, namely to call the adolescent (Asteriska) adek partner who was still in early childhood education. The implicature states that it arises due to positive politeness violation. The results of the analysis are in accordance with the results of a study conducted by Nur Ifansyah $\&$ Sumarlam (2017) which states that the mention implicature was created as a result of positive politeness violation. Such a term is a threat to the wishes of the speech partner so that what they have is appreciated by the speaker.

The next data is representative action.

Context: Vincent and Desta performed the "who is ..." segment with guest stars are Aldy, Kiki, and Bastian. They are ex of personnel of the Coboy Junior boy band. The first question was read by Desta. 
Desta: "Who is the most often forget the lyric?"

Bastian: "it's easy"

Vincent: "show it please"

Desta: "Aldy answered Bastian, Kiki answered Bastian, and Bastian answered me. Is there anyone in Coboy Junior whose name is me?"

Vincent: "no no, that's himself" (TS-24/03/20)

The data stated that the speaker (Desta) did not intend to ask for an answer. With the questioning mode he wanted to speak in a representative manner to invite humor. The results of the analysis are in accordance with the results of study by Nur Ifansyah \& Sumarlam (2017) which mentions in the humor discourse, that action is solely for humor.

Context : after Bastian gave a reason that he often forgets lyrics, Desta give an answer.

Desta: "it's ok, because Bastian must have changed now and there has been progress"

Bastian: "must be"

Kiki: "not really"

Bastian: "it's not like that. It's crazy" (TS-24/03/20)

The next data contain satirical implicature with express mode. The implicature is due to the between the cooperative principles and politeness violation. What is meant by the speaker (Kiki) is not addressed to the speech partner (Desta) but rather to Bastian. The quality maxims violation actually becomes the subject of the audience's laugh because they know the deviation of that fact. Positive politeness is violated because satire is an act that does not respect the situation of a person being insinuated. The results of the analysis are in accordance with the results of research by Nur Ifansyah \& Sumarlam (2017) who stated that implicatures arise from the cooperative principle violation and the politeness principle.

Context: Bastian, Kiki, and Aldy answered the questions posed by Desta about who often do face treatment, but Bastian has different answers and they argue with each other.

Bastian: "does he really do face treatment? Maybe he does make up for long time"

Aldy: "Is it treatment?" 
The Implication of humor discourse in the Tonight Show ...(Dita Intan Pramukti, Asep Purwo Yudi Utomo)

Vincent: "No."

Aldy: "see, it's not treatment"

Desta: "Don't fight, don't fight"

Desta: "You ever fought before, now you don't have to fight anymore" (TS-24/03/20)

The next data contain satirical implicature with express mode. The implicature occurs due to the cooperative principle violation and the politeness principle. What is meant by the speaker (Desta) is not addressed to the speech partner (Aldy) but rather to Bastian. Because Bastian used to fight with other pesonil. The quality maxims violation actually becomes the subject of the audience's laugh because they know the deviation of that fact. The positive politeness is violated because innuendo is an act that does not respect the situation of a person being insinuated. The results of the analysis are in accordance with the results of research by Nur Ifansyah \& Sumarlam (2017) who stated that implicatures arise from the cooperative principle violation and the politeness principle.

Context : Vincent asks Bastian, Kiki, and Aldy questions about who is the most annoying of them. Then Desta gave the idea that Bastian, Kiki, and Aldy answered that who is the most annoying was Iqbaal.

Vincent: "Who is the most ignorant. nosy, fad"

Desta: "If you want to answer Iqbaal, it's okay, too"

Vincent: "It's okay"

Desta: "because Iqbaal was watching there too"

Vincent: "Oh, in Australia?"

Desta: "on YouTube” (TS-24/03/20)

The utterance of the speaker (Vincent) used the questioning mode, but has a pragmatic function of protesting. The action is a form of evaluation of the words of the speech partner (Desta) which can cause in the positive face of the speech partner that is being threatened. The protest delivered was actually able to arouse the audience's laughter because the word contained elements of jokes, which differed from what was protested. The results of the analysis are in accordance with the research results of Nur Ifansyah \& Sumarlam (2017) who stated that this action as an evaluation of what was said by the speech partners.

Context: Desta challenges Bastian to flattery compete with the selected words. Then Vincent chooses one of the crew from NET TV. 
Desta: "Vincent please choose the girl"

Vincent: "Oh, beautiful woman"

Desta: "yes please"

Bastian: "know, already know"

Vincent: "here it is, NET crew, net pingpong " (TS-24/03/20)

In the conversation above there are speech acts that are not in accordance with the function carried. The speaker (Vincent) spook in the mode of telling, but it contains pragmatic implicature of humor. The results of the analysis are in accordance with the results of research by Nur Ifansyah \& Sumarlam (2017) which states in the humor discourse, that action is solely for the sake of humor.

\section{Conclusion}

In creating an atmosphere of humor, actors interacting in the Tonight Show program often use indirect speaking strategy, namely by utilizing implicature. There are many forms of implicature expressed, namely mentioning, insinuating, revealing, protesting, informing, rejecting, accusing, asking, saying. The implicature's existence is due to not prioritizing the conversation principle, both the cooperative principle and the politeness principle. However, the conversation continued to run smoothly and did not threaten social relations between them. It can happen because of the similarity of understanding about the contribution they give to the interaction, only to raise a comic effect.

\section{Suggestion}

Based on the study conducted, some suggestions that can be delivered are the use of humor language, and a language understanding is needed by involving the text, context, and references for the community to understand the purpose and function behind the humor discourse.

Also, for other researchers, it is hoped that this study can be used as a reading that can be understood to conduct pragmatic study topics in the form of implicature in other humor discourse. Due to the limitations of the research on the humor discourse's implicature on the Tonight Show, it is recommended that further analysis can be carried out sincerely. 
The Implication of humor discourse in the Tonight Show ...(Dita Intan Pramukti, Asep Purwo Yudi Utomo)

\section{REFERENCES}

Astuti, W. D. (2017). Implikatur percakapan dalam gelar wicara "Sentilan Sentilun” di Metro TV. Kandai, 13(2), 311.

Bell, N., \& Pomerantz, A. (2015). Humor in the classroom: A guide for language teachers and educational researchers. Routledge.

Fadilah, E. R. (2015). Humor dalam wacana Stand-Up Comedy Indonesia Season 4 di Kompas TV (Doctoral dissertation, Universitas Negeri Semarang).

Faridl, A. M. (2011). Implikatur-implikatur percakapan dalam wacana humor Gus Dur. Skripsi. Univesitas Sebelas Maret Surakarta.

Irfansyah, N., \& Sumarlam, S. (2017). Implikatur wacana humor gelar wicara Ini Talkshow di Net TV. BAHASTRA, 37(1), 49-57.

Mitang, M. P. (2020). Wacana humor kritik sosial dalam Stand Up Comedy Indonesia Season 4 di Kompas TV: Tinjauan pragmatik. Sintesis, 14(1), 78-93.

Pudyastuti, L. A., \& Zamzani, Z. (2019). Implikatur percakapan dalam pembelajaran bahasa Indonesia di sekolah. Widyaparwa, 47(1), 21-32.

Purnomo, H. (2015). Implikatur percakapan dalam wacana kartun Si Jujun pada media masa cetak koran Solopos edisi Januari sampai Maret 2015 (Doctoral dissertation, Universitas Muhammadiyah Surakarta).

Rizkie, I. H. (2013). Pelanggaran prinsip kerja sama dan implikatur wacana humor dalam rubrik "Mesem" Surat Kabar Harian Warta Jateng (Doctoral dissertation, Universitas Muhammadiyah Surakarta).

Saputri, N. I. (2013). Implikatur dan inferensi dalam buku humor anak sekolah karya drs. BP Habeahan (Doctoral dissertation, Universitas Muhammadiyah Surakarta).

Sulistiani, R. (2018). Implikatur percakapan dalam wacana humor komik kartun sentilan Bung Sentil (Doctoral dissertation, Universitas Negeri Jakarta).

Tiani, R. (2014). Implikatur humor sebagai kritik sosial pemerintahan. Seminar Nasional Prasasti. Solo.

Ustari, P. (2019). Pelanggaran prinsip kerja sama dan implikatur percakapan dalam acara "Waktu Indonesia Bercanda" di NET TV (Doctoral dissertation, UNNES).

Informan 1. (2020, 17 March). Youtube

Informan 2. (2020, 17 March). Youtube 
Journal of Social Studies (JSS), Volume 15, Number 2, 2019: 145-162

Informan 3. (2020, 17 March). Youtube Informan 4. (2020, 17 March). Youtube Informan 5. (2020, 17 March). Youtube Informan 6. (2020, 17 March). Youtube Informan 7. (2020, 17 March). Youtube Informan 8. (2020, 17 March). Youtube Informan 9. (2020, 24 March). Youtube Informan 10. (2020, 24 March). Youtube Informan 11. (2020, 24 March). Youtube Informan 12. (2020, 24 March). Youtube Informan 13. (2020, 24 March). Youtube 